\title{
Debt Collection of Financial Technology Lending
}

\author{
Gika Asdina Firanda ${ }^{1 *}$, Paramita Prananingtyas ${ }^{1}$, Sartika Nanda Lestari ${ }^{1}$ \\ \{gikafiranda@gmail.com*1 ${ }^{*}$ paramitaprananingtyas@live.undip.ac.id ${ }^{2}$ \\ sartikananda@live.undip.ac.id\}
}

Fakultas Hukum, Universitas Diponegoro, Jl. Prof. H. Soedarto, S.H., Tembalang, Semarang, Indonesia $50275^{1}$

\begin{abstract}
Peer-to-peer (P2P) Lending or known as an Online Loans is an alternative way to borrowing money based on information technology. Unlike credit in banking, P2P Lending does not adhere to the principle of 5C (Character, Capacity, Capital, Collateral, Condition) as a reference for eligibility, and therefore many do not pay it off and this rises the use of debt collectors. Financial services authority (OJK) is a regulatory agency authorized to oversee P2P Lending as a whole. The problem that forms the basis of this research is how financial services authority supervises and follows up towards debt collector's problems of P2P Lending. The method used in this research is normative juridical approach with descriptive-analytical. The analysis method used is qualitative. This research uses the secondary data obtained from the literature study consisting of primary, secondary, and tertiary legal materials. Based on the research, it concludes the authority and supervision of OJK in P2P Lending based on three ways, namely on-site, off-site, and market conduct. In a market conduct, OJK appoints an association that will assist them in terms of regulation and supervision of P2P Lending. The follow up of the OJK regarding the problem of debt collection is through written sanctions to revocation of the P2P Lending provider's business license.
\end{abstract}

Keywords: P2P Lending, Otoritas Jasa Keuangan Supervision, Debt Collection.

\section{Introduction}

In this digital age, everything is easily accessible and obtainable. The impact of the rapid development of technology has also penetrated the Indonesian financial industry. Economic actors can deal with any transaction online. So this has led to the emergence of a new economic system to develop Indonesia's digital economy, called Financial Technology or commonly abbreviated as Fintech.

There are several classifications at Fintech namely payment startup, lending, financial planning (personal finance), retail investment, financing (crowdfunding), remittance, financial research, and others.

P2P Lending is one of the most popular Fintech products. The number of the company keeps growing. In the end of 2018, the value of P2P lending loans reached IDR. 13.83 trillion. In fact, P2Plending contribution to the domestic reaches IDR. 22.67 trillion in 2018.[1] P2P lending is the organization of financial services to bring together lenders and loan recipients to enter into a loan agreement through an information technology system or more commonly referred to as online loans. 
P2P Lending is based on a legal protection after the issuance of the Financial Services Authority Regulation (POJK) No. 77/POJK.01/2016 concerning Information TechnologyBased Lending and Borrowing Services.[2] In this regulation, OJK regulates various matters that must be adhered to, especially for P2P Lending actors. The Financial Services Authority $(\mathrm{OJK})$ is an independent institution that has functions and duties in the implementation of an integrated system of regulation and supervision of financial services, one of which is Fintech. Although it is already is regulated, there are some problems and legal vacuum in P2P Lending still arise.

Problems caused by various kinds, one of the most widespread regarding the collection of debt that is not appropriate and violates the law committed by the debt collectors (Debt Collector). OJK, in this case, which oversees Fintech should formulate and review the regulations regarding the Debt Collector, in order to provide legal protection for consumers as borrowers and investors as lenders.

Based on the background description above, it is necessary to formulate what is the problem. The formulation of the problem that will be discussed in writing this law is:

What is the authority and supervision of the Financial Services Authority (OJK) over Debt Collectors based on Financial Technology-based online loans in Indonesia?

1. How is the supervision and enforcement of the Financial Services Authority (OJK) over debt collection by a debt collector (Debt Collector) on an online loan based on Financial Technology?

The objectives to be achieved with this research are as follows:

1. To find out and analyze the authority and supervision of the Financial Services Authority (OJK) of Financial Technology Debt Collectors in Indonesia.

2. To find out and analyze how the Financial Services Authority (OJK) follows up if there are problems in the debt collection system conducted by the Debt Collector.

\section{Method}

The method of approach used in writing this law is the normative juridical approach. Soerjano Soekanto states that the normative juridical approach is a legal research conducted by examining literature or secondary data as a basic material to be investigated by conducting a search of the regulations and literature relating to the problem under study. [3] The research was conducted by examining and looking at the theoretical law related to legal principles, legal comparisons and what happened in the field related to problems.

\subsection{Research Specifications}

Analytical descriptive research is a method that serves to describe or give an overview of the object under study through data or samples that have been collected as they are without conducting analysis and making conclusions that are applicable to the public.[3]

\subsection{Sources and Types of Data}

The type of data that will be used in writing this law is secondary data consisting of primary legal materials, secondary legal materials, and tertiary legal materials. In addition, previous studies relating to the issues to be discussed also become one of the data sources in the form of laws, regulations, literature and related scientific papers. Secondary data that will be used later consists of: 
a. Law Number 21 of 2011 concerning the Financial Services Authority

b. Financial Services Authority Regulation No. 77/POJK.01/2016 concerning Financial Information Technology Lending and Borrowing Services;

c. Code of Conduct of Information Technology Based Borrowing and Borrowing Services Responsibly by the Indonesian Fintech Association.

Secondary legal materials consist of:

1. Books;

2. Journals;

3. Dissertation, Thesis, and Legal Thesis; and

4. Papers.

Tertiary legal material consists of:

1. Large Indonesian Dictionary;

2. Popular Scientific Dictionary;

3. Legal Dictionary;

4. Legal Encyclopedia; and

5. Internet.

\section{Research Results and Discussion}

\subsection{Authority and Oversight of the Financial Services Authority (OJK) Against Financial Technology Debt Collectors in Indonesia}

The presence of Fintech in Indonesia does have its own impact on the development of the financial services sector. Like two sides of a coin, this industry has good and bad effects. The good side with the existence of this industry is encouraging expansion of access to financial loans to people who do not have bank accounts or limited credit, making it easier for someone to make loans. Nevertheless, on the reverse side, the lack of regulations governing financial services has led to many cases. Cases arising from a variety of cases ranging from loan interest that is felt to suffocate the borrowers, misuse of personal data, to the most widespread is the problem of debt collection that goes beyond the norm and legal limits.

In Indonesia, there are institutions tasked with overseeing P2P Lending financial services activities. Based on Article 5 of Law Number 21 of 2011 concerning the Financial Services Authority,[4] OJK has the function of organizing an integrated regulation and supervision system for all activities in the financial services sector.

In this case, Fintech entered the Non-Bank Financial Industry (IKNB) sector. Furthermore regarding supervision, in accordance with articles 6 and 9 of Law Number 21 of 2001 concerning the Financial Services Authority, OJK has the authority to conduct supervision, inspection, investigation, consumer protection, and other actions towards financial service institutions, actors, and/or supporting financial services activities as referred to in legislation in the financial services sector and establishing administrative sanctions against those who violate the laws in the financial services sector.

Supervision of P2P Lending in general is three, namely off-site (indirect), on-site (direct) and market conduct supervision. Regarding off-site supervision (indirect) is carried out by examining documents and reports provided by the P2P Lending Operator which later the OJK 
will examine based on reports and documents provided by the P2P Lending Provider. Whereas on-site supervision is carried out based on periodic inspection plans which are generally conducted once a year. Finally, market conduct is conducted by OJK by inviting industry players, including organizers, the public, and related institutions to participate in supervising Fintech. In this case the association was appointed as an institution that oversees the running of Fintech.[5]

Market conduct is part of the rules and supervision of financial institutions that focus on the behavior of irregularities and abuse of power in the inclusion of information, this aims to ensure that financial institutions provide good services to consumers. [6] The concrete form of this market conduct is to form an association that will later supervise and help OJK to formulate regulations related to $\mathrm{P} 2 \mathrm{P}$ Lending, so it can be concluded that the association is an extension of OJK related to regulation and supervision. [5] The formation of associations is contained in Article 21 paragraph (1) POJK No. 13/POJK.02/2018 Digital Financial Innovation, that the organizer forms the organizers association.[7] Further explained in Article 21 paragraph (3), the association will have the authority to set standards by using a market discipline approach that applies to its members including:

a. Formulate operating rules, industry standards and codes of ethics, according to different types of businesses;

b. Receive and forward reports and receive complaints;

c. Compile financial statistics and monitor risks as well as research on macro and micro financial issues;

d. Become a liaison between the Financial Services Authority and the Operator to improve regulatory support and information exchange;

e. Establish mechanisms of self-regulation and sanctions for violations of members of the rules and code of ethics; and

f. Carry out education, training, and consumer protection and domestic and international cooperation.

In accordance with the mandate of POJK No. 13/POJK.02/2018, OJK appointed 2 (two) official associations recognized by the OJK namely the Indonesian Joint Funding Fintech Association (AFPI) and the Indonesian Fintech Association (AFTECH). In accordance with Article 21 paragraph (3) POJK No. 13/POJK.02/2018, the association has the authority to formulate operating rules, industry standards, and code of ethics by making guidelines or code of conduct that must be obeyed by P2P Lending organizers registered in the association. In this regard, AFPI and AFTECH have established Information Technology-Based Information Lending and Borrowing Guidelines. Although not issued directly by the OJK, but with the FSA giving authority to the association to make regulations, the guidelines must be obeyed by P2P Lending Organizers. In addition, the association has a role as a bridge or container for Fintech actors, to provide legal protection for users of Fintech services and increase regulatory support and information exchange. In the implementation of market conduct, OJK also made a new approach, namely principle based regulation and activity based licensing, which means OJK only outlines the principles, while the translation of these arrangements will be made by industry players.[5]

Based on the principle of principle-based regulation, OJK as a regulatory body only makes principles-based arrangements while further arrangements related to business operational standards are formulated by industry players. It can be concluded that in addition to OJK overseeing itself, OJK also supervises through associations. This is related to the principle of independent monitoring, where industry players supervise their own business 
including the principles of information technology governance, consumer protection, education and outreach, data confidentiality including transaction information, risk management and prudential principles, anti-money laundering and funding principles terrorism, as well as inclusive and principles of information disclosure.

The principle of pro-innovation is also applied by OJK through the implementation of regulatory sandbox, which is a testing mechanism by OJK to assess the reliability of business processes, business models, financial instruments, and governance of administrators. This regulatory sandbox is regulated in POJK No. 13/POJK.02/2018 concerning Digital Financial Innovations. Previously, OJK took repressive measures to supervise P2P Lending through associations by reviewing each other and seeing problems in P2P Lending, different from regulatory sandboxes. This approach was chosen because of the rapid development of digital technology that cannot be matched by the speed of rule making. The way this regulatory sandbox works is that before the business idea of the Fintech platform is operational or launched it must go through a trial phase to get permission.

In particular, supervision of debt collection and debt collectors is not explicitly regulated in POJK. As explained earlier based on the principle of principle based regulation, OJK only regulates basic principles that must be obeyed by Fintech industry players while operational activities and standards are regulated by industry players through association. Then the arrangement regarding debt collection and debt collector is the authority of the association to regulate it because it is related to the code of ethics and rules of operation. However, the general provisions that must be carried out by the Provider including regarding debt collection remains regulated implicitly by the OJK. For example in Article 31 POJK No. 13/POJK.02/2018, the Operator is obliged to apply the basic principles of consumer protection, namely:

a. Transparency;

b. Fair treatment;

c. Reliability;

d. Confidentiality and security of consumer data/information; and

e. Handling complaints and solving consumer disputes is simple, fast, and affordable.

The principles mentioned above relate to things that the Operator must do on debt collection but does not explain in detail how to procedure for debt collection that is good and right or the arrangements regarding the services of third parties or debt collectors when debt collection. Because of that, the association that formed more detailed regulations related to debt collection.

AFTECH and AFPI as P2P Lending associations have issued a Code of Conduct for Information Technology-Based Lending and Borrowing Services that contains guidelines on behavior, principles and processes that must be carried out to provide ethical references on the conduct of responsibilities for Organizers voluntarily, jointly, and bindingly. The code of conduct is based on three basic principles, one of which is the application of the principle of good faith, explained that in facilitating the offering and lending activities as a platform or marketplace, each Operator is still required to apply the principle of good faith by taking into account the interests of all parties involved, and without degrading the dignity and user dignity.[8]

Applying the principle of good faith if it is associated with debt collection, the Provider cannot arbitrarily bill the Recipient of the defaulted Loan. Before conducting a collection, the Provider must submit the settlement and billing procedures to the Lender and Receiver of the Loan. This is done so that the Lender and Recipient know what are the procedures that must 
be carried out to resolve the problem if there is a loan recipient who defaulted. The steps taken by the Operator in solving problems based on hierarchy must be carried out by the Operator in advance such as giving a warning letter that the payment has passed or is past due in accordance with the agreement. If there is a warning letter, the Loan Recipient does not pay, the Operator makes the loan scheduling or restructuring requirements. Providers in conducting long-distance billing can be done via telephone, email, or other forms of conversation while if you want to visit the Organizer directly through the billing team must first communicate with the Loan Recipient.

The organizer is not allowed to carry out direct billing if it has exceeded the limit of more than 90 (ninety) days from the due date. The organizer is also required to inform the Loan Recipient in detail if the loan is not completed. Although the Loan Recipient fails to pay, the Provider must still pay attention to the consumer's protection of the Loan Recipient because it is a right that must still be granted and guaranteed legal certainty based on Article 3 POJK No. 1/POJK.07/2013 concerning Consumer Protection in the Financial Services Sector that:

"Financial Service Institutions have the right to ensure the goodwill of consumers and obtain information and/or documents about consumers that are accurate, honest, clear, and not misleading." [9]

Same thing with the Loan Recipient, the Provider and Lender also have the right to be paid by the Organizer. So the Loan Recipients, Lenders, and Organizers should know their rights and obligations as a P2P Lending business actor so that problems do not occur in the future.

In the Code of Conduct of Responsible Information Technology Lending and Borrowing Borrowing Services mentioned in Point 4 that the use of third parties in debt collection or called debt collectors is allowed in P2P Lending. However, if the Provider uses the services of a third party, he must pay attention to several things, namely:

a. Each Operator is allowed to use a third party billing service company that has registered with AFPI and has a certificate to bill borrowers that are also issued by AFPI through the audit mechanism of the Billing Implementation Guidelines and also the Financial and Operational audits of the company. All billing employees from billing services companies are also required to obtain Billing Agent certification issued by AFPI;

b. Each Operator is permitted to use a third party billing service company that has been recognized for bills that have passed the delay limit of more than 90 (ninety) days calculated from the due date of the loan;

c. Each Operator is prohibited from using a third party billing implementation company (both individuals and corporations) who are classified in the authority and/or association's blacklist.

d. The black list referred to above will be compiled later in the periodic updating of the Code of Conduct.

Organizers in using the services of third parties must pay attention to procedures for billing conducted based on the principle of good faith. Problems with P2P Lending that often occur due to debt collection that is not in accordance with the principles of good faith and misuse of personal data that should be protected by confidentiality. Debt collectors who have violated the code of ethics will be included in the blacklist of the authority and the FSA and can no longer be used services. All forms of physical and mental violence at the time of 
collection are also strictly prohibited, this prohibition states that each Operator as the authorizer of the Lender is prohibited from billing by intimidation, physical and mental violence, or other methods that offend SARA or lower the dignity, dignity, and price Loan Recipients themselves, in the physical world and in cyberspace (cyber bullying) both of the Loan Recipients, their property, or relatives and family.

Code of conduct in the form of Technology-Based Behavior Guidelines for Lending and Borrowing Money Based on Technology made by associations must be obeyed by P2P Lending Organizers because association rules are also OJK rules. So that if the P2P Lending Operator violates the code of conduct, the OJK can act firmly based on sanctions that have been set both by the association and the OJK. So, the billing procedures that have been described in these guidelines must be obeyed by registered P2P Lending Organizers. [5]

Based on further explanation regarding OJK's supervision of P2P Lending that has been elaborated, OJK as a regulatory agency conducts supervision based on the principle of principle-based regulation and activity-based licensing, which means OJK only regulates the basic principles of the rest of the regulations regarding the rules of the game formulated by P2P industry players Lending. Other arrangements regarding the standard aspects of operations, business conduct, and business ethics are formulated by industry players who are recognized and jointly carried out. In this case, the Organizer and OJK form an association that regulates this matter. The association will coordinate intensively with OJK so that supervision can run effectively, efficiently and optimally. So based on these principles it is not the authority of the FSA to regulate in detail regarding debt collection, but the FSA continues to supervise through the association.

\subsection{Follow-Up of the Financial Services Authority (OJK) Against Debt Collection Problems Conducted by Debt Collectors}

\subsubsection{Problematic and Illegal Debt Collection}

Debt collection problems in P2P Lending are increasingly prevalent. Although there are already institutions that oversee P2P Lending, there are still many cases that occur related to debt collection that is not ethically appropriate and violates the law and misappropriation of customer data. Debt collection is the problem most complained of by consumers in 2019.

In 2019, the Indonesian Consumers Foundation (YLKI) received 77 (seventy seven) complaints related to Fintech. Of the total number of complaints, consumers most often complain about the way to collect online loans, amounting to 26 (twenty six) complaints. Furthermore, from the category of default, there were 21 (twenty one) complain ts, distribution of personal data of 12 (twelve) complaints, and high interest of 8 (eight) complaints. [10] Whereas AFPI has received 426 (four hundred twenty-six) complaints since 2019. The majority complained about billing in a rude manner and access to personal data by Fintech loans. Reports about billing that made roughly reached 43 percent of the total complaints. Then, 41 percent of complaints related to access to personal data. Then, 10 percent reported that Fintech's interest and penalty fees were too high.[11]

One of them is Mawar (a pseudonym). Mawar is a P2P Lending customer. In February 2019, she borrowed Rp2 million from a P2P Lending Operator., Since she was unable to pay them all, she was billed by debt collectors. Mawar said she was threatened by collectors in abusive language, and had also been told to end her life so that her debts were paid off. Not only threatening the rose while doing the collection, the debt collectors also spread information about the loan made by Mawar to friends, family, and even her workplace via SMS and forced Mawar to quickly pay off her debt. 
Felice, also shared his experience with an online loan company. The amount of money borrowed as much as Rp 1 million. Before his loan was due, Felice was billed with a rude language. After piling up debt in the application, Felice receives a call from a debt collector who offers a total write off of all principal costs and interest on the loan but must dance naked in front of the debt collector. This put great pressure on Felice and he finally reported to the Legal Aid Institute (LBH).

The cases described simply explain the polemic that occurred in debt collection in $\mathrm{P} 2 \mathrm{P}$ Lending. Although the Provider has the right to pay its debts as the Loan Recipient has promised, the Provider still may not collect debts using violence and threats and the Provider is prohibited from distributing Loan Recipients' personal data.

This case can occur because of the lack of regulations governing debt collection, this can be seen in POJK No. 77/POJK.01/2016 which regulates licensing, registration, risk mitigation, data confidentiality, and the position of loan recipients and loan recipients but does not cover debt collection and debt collectors in detail. Then the sanctions in the code of conduct owned by the association are not strong enough because they do not have strict sanctions to take action if there are problems with debt collection. The association can only provide sanctions in the form of written reprimands, publication of the names of members and provisions violated to OJK and the community, as well as permanent termination of association membership. This sanction is felt to be less strict because it does not provide a deterrent effect to the perpetrators or organizers who violate it.

\subsubsection{OJK Follow-Up against P2P Lending, Especially Debt Collectors that Break the} Law

Violation of debt collection in P2P Lending will continue to be a problem if the OJK or the Government does not take decisive steps to the perpetrators. OJK as a regulatory agency that has the authority to take action against P2P Lending businesses that violates the basic principles of consumer protection include transparency, fair treatment, reliability, confidentiality and security of data/information, handling complaints and settling consumer disputes in a simple, fast, and affordable cost and good faith in POJK No. 13/POJK.02/2018. In Article 39 POJK No. 13/POJK.02/2018, for P2P Lending that provides data and/or information about consumers to third parties, OJK has the authority to impose administrative sanctions on those who commit violations in the form of:

a. Written warning;

b. Fines, namely the obligation to pay a certain amount of money;

c. Cancellation of approval; and/or

d. Cancellation of registration.

Imposing sanctions against $\mathrm{P} 2 \mathrm{P}$ Lending Organizers is seen from the extent of the mistakes which is then reviewed by OJK which sanctions are appropriate for $\mathrm{P} 2 \mathrm{P}$ Lending Organizers who violate the rules. Administrative sanctions may be imposed with or without prior administrative sanctions in the form of written warnings and administrative sanctions may be imposed jointly with administrative sanctions. In addition to those stipulated in this article, the OJK has the authority to take certain actions against any party that violates the POJK provisions.

The Code of Conduct for Responsible Lending and Borrowing of Money Based on Information Technology Responsibly also regulates sanctions if association members violate the debt collection ethics. The sanctions are not much different from those in POJK No. 13/POJK.02/2018, only the imposition of sanctions is limited to association members. 
Consumers who are victims of debt collectors are basically protected by their consumer rights in POJK No. 1/POJK.07/2013 concerning Consumer Protection in the Financial Services Sector. For OJK Consumers who feel disadvantaged by P2P Lending debt collection can report the P2P Lending to OJK. OJK has two ways for the settlement process if there are problems between the Provider and the Loan Recipient. In the first stage, OJK will facilitate consumers to be brought together by business service providers with the platform providers to meet. If the meeting does not produce results, the FSA will continue the problem into the realm of law.

\subsubsection{Legal Safeguards Against Borrowers in P2P Lending}

As a first step towards legal protection and regulation of P2P Lending, OJK has issued POJK No. 77/POJK.01/2016 concerning Information Technology-Based Money Lending and Borrowing Services. This POJK can be said to be the first POJK formulated by the OJK in the Fintech realm. That is because OJK sees the urgency of the strong culture of lending and borrowing in Indonesian society. This POJK regulates the registration and licensing of P2P Lending, this is one of the legal protection efforts for Borrowers. Because P2P Lending is registered and has a license supervised by the OJK, so if there is a problem between the Borrower and the P2P Lending Provider can report to the OJK.

OJK as a regulator has its own authority limits. So it is important for OJK to increase synergy with other institutions that can help OJK to provide legal protection to P2P Lending. The formation of associations is also a step for OJK to seek consumer protection. The association will work closely with OJK to formulate policies related to consumer protection in P2P Lending. Such as formulating a code of ethics through the Code of Conduct for Responsible Lending and Borrowing of Money Based on Information Technology in which it regulates the procedures for billing and debt collectors and provides P2P Lending consumer complaint services.

Education and notification to the public through press releases and seminars organized by the FSA is very necessary so that the wider community is not blind and can be more careful of all aspects of $\mathrm{P} 2 \mathrm{P}$ Lending, especially consumer protection.

The consumer or recipient of the loan can complain about the problematic debt collector. In accordance with POJK No. 18/POJK.07/2018 concerning Consumer Complaint Services in the Financial Services Sector.[12] Consumers who wish to report to OJK must fulfill the requirements stated in Article 10 POJK No. 18/POJK.07/2018, by completing documents consisting of:

a. Consumer Identity and/or Consumer Representative;

b. Special power of attorney;

c. Types and dates of financial transactions; and

d. The problem complained of.

OJK can reject complaints if the documents and requirements submitted are not complete. Furthermore, the FSA is obliged to serve the incoming complaints by conducting internal checks and analyzing the truth of complaints. Complaints can also be submitted to associations such as the Indonesian Funding Fintech Association (AFPI). AFPI opened a complaint center called JENDELA as a channel for information and customer complaints for P2P Lending. AFPI openly listens to customer complaints by providing customer service, hotline centers by telephone or e-mail. 


\section{Conclusion}

1. OJK's Authority and Supervision of P2P Lending in general are 3 (three), namely off-site (indirect), on-site (direct) and market conduct supervision. In addition to conducting these three supervision, OJK as a regulator also makes regulations on financial services authorities. However, OJK does not directly regulate the procedure for debt collection in $\mathrm{P} 2 \mathrm{P}$ Lending or debt collector; this is based on the principle of principle-based regulation that OJK only regulates matters that are in principle only subsequently regarding standard operating procedures and rules of play formulated by financial service industry players. Based on market conduct supervision, OJK invites financial service industry players to participate in supervising P2P Lending. So OJK appoints and forms an association that is authorized to make regulations regarding standard operating procedures and codes of conduct on P2P Lending. One of the regulations made by the association is the Information Technology Lending and Borrowing Lending Behavior Guidelines. This guideline regulates good faith in collection of default loans and good faith as well as third-party users in collection, which in essence is to collect debts, the organizer is obliged to collect properly and must not use threats, harsh words, even violence. This guideline must be implemented by P2P Lending business actors registered with OJK and associations. The position of the guidelines made by this association is almost the same as POJK. In other words, if the P2P Lending Operator violates the code of conduct, the association can report this to the OJK and the OJK can act against the P2P Lending Operator. In the end, OJK will impose sanctions according to the extent of violations committed by P2P Lending Organizers.

2. OJK will oversee and enforce P2P Lending Organizers and debt collectors who are proven to misconduct against law and ethics either by providing sanctions in the form of written warnings, fines, or the cancellation of registration to the P2P Lending Operator. Whereas for individual debt collectors who commit violations, OJK will put the debt collector's name in a blacklist of authorities who will later be P2P Lending Providers prohibited from using the debt collector's service again in debt collection. Besides OJK's efforts to protect consumers/customers in P2P Lending in addition to POJK, customers can also report P2P Lending to OJK and its associations. However, this can be done only if $\mathrm{P} 2 \mathrm{P}$ Lending is registered and has permission from OJK. OJK can still crack down on P2P Lending perpetrators along with KOMINFO and Bareskrim by blocking illegal P2P Lending sites and applications. OJK also conducts counseling by organizing seminars related to P2P Lending and press releases as a preventive effort so that people can be more careful in using P2P Lending.

\section{Suggestion}

1. OJK should make more detailed arrangements regarding debt collection and debt collectors on P2P Lending through POJK because the existing regulations are not enough to provide legal protection for borrowers. OJK must be more assertive and detailed in regulating restrictions that may not be imposed by debt collectors and restrictions that may be imposed on debt collection. Moreover, clarify the position of debt collectors on P2P Lending. In addition, OJK along with the government through KOMINFO should also regulate and supervise the protection of personal data by immediately drafting 
legislation related to personal data protection. So there is no misuse of personal data as often happens in debt collection.

2. In following up the debt collection problem at P2P Lending, OJK must be more assertive in imposing sanctions on those who violate the ethics of debt collection. OJK must also maximize alternative dispute resolution institutions so that if there are problems with default, it can be resolved through OJK. In this case, the P2P Lending Provider does not have to threaten and force to use force when collecting debt and can find a win-win solution for Loan Recipients with the P2P Lending Provider. In addition, OJK must encourage associations to immediately realize the debt collector certification. In addition, the FSA should be more active in coordinating with the Indonesian National Police and National Police regarding illegal P2P Lending and giving strict sanctions to financial service industry players involved in illegal P2P Lending. Not only blocking illegal P2P Lending applications and sites, they are also cracking down on the perpetrators by providing sanctions in the form of criminal sanctions and fines. So the government felt it was necessary to make a law relating to illegal investment, especially in the Fintech industry. 


\section{References}

[1] F. Sari, "Ini daftar 99 fintech lending yang terdaftar dan berizin di OJK," 2 Feb 2019. [Online]. Available: https://keuangan.kontan.co.id/news/ini-daftar-99-fintech-lendingyang-terdaftar-dan-berizin-di-ojk. [Accessed: 09-Apr-2019].

[2] Financial Services Authority Regulation (POJK) No. 77/POJK.01/2016 concerning Information Technology-Based Lending and Borrowing Services. .

[3] and M. S. Soekanto, S., Penelitian Hukum Normatif: Suatu Tinjauan Singkat. Jakarta: Rajawali Pers, 2009.

[4] Law Number 21 of 2011 concerning the Financial Services Authority.

[5] Interview with Regional Financial Services Authority (OJK) Representative 3, Semarang, on August 27, 2019. .

[6] Otoritas Jasa Keuangan (OJK), "Siaran Pers: OJK Dukung Kemajuan Teknologi Keuangan Digital, Gelar Sosialisasi Peraturan Inovasi Keuangan Digital di Makasar," 2018. [Online]. Available: https://www.ojk.go.id/id/berita-dan-kegiatan/siaranpers/Documents/Pages/Siaran-Pers-OJK-Dukung-Kemajuan-Teknologi-KeuanganDigital/SP IKD Makassar.pdf. [Accessed: 22-Aug-2019].

[7] Financial Services Authority Regulation (POJK) No. 13/POJK.02/2018 concerning Digital Financial Innovation. .

[8] Asosiasi FinTech Pendanaan Bersama Indonesia (AFPI), "Pedoman Perilaku Pemberian Layanan Pinjam Meminjam Uang Berbasis Teknologi Informasi Secara Bertanggung Jawab," 7 Mar 2019. [Online]. Available: https://drive.google.com/file/d/1Wb5nONxttwc3T9zG2XUZXRp4jCMx7DJK/view. [Accessed: 22-Aug-2019].

[9] Financial Services Authority Regulation (POJK) No. 1/POJK.07/2013 concerning Consumer Protection in the Financial Services Sector. .

[10] R. Wulandari, "Konsumen Fintech Banyak Adukan Cara Penagihan Utang," 1 Aug 2019. [Online]. Available: https://republika.co.id/berita/pvjldd382/konsumenemfintechem-paling-banyak-adukan-cara-penagihan-utang. [Accessed: 22-Aug-2019].

[11] D. Angriani, "Meneropong Penagihan Fintech Lending," 28 May 2019. [Online]. Available: $\quad$ https://www.medcom.id/ekonomi/analisa-ekonomi/JKRVoP5Kmeneropong-penagihan-fintech-lending. [Accessed: 19-Aug-2019].

[12] Financial Services Authority Regulation (POJK) No. 18/POJK.07/2018 concerning Consumer Complaint Services in the Financial Services Sector. . 